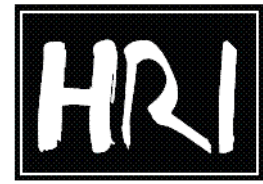

THE HUMAN RIGHTS INSTITUTE

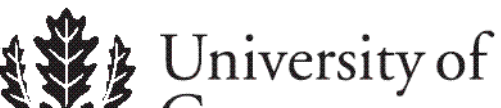

4 Connecticut

Economic Rights Working Paper Series

\title{
Human Rights and Human Development
}

Sakiko Fukuda-Parr

The New School

Working Paper 4

November 2007

The Human Rights Institute University of Connecticut Thomas J. Dodd Research Center

Email: humanrights@uconn.edu

405 Babbidge Road, U-1205

Tel: 860-486-8739

Storrs, CT, 06269, USA

Fax: 860-486-6332

http://www.humanrights.uconn.edu/ 


\begin{abstract}
This paper uses Sen's capability approach to explore whether there are inherent contradictions between human rights and development. Sen's capability and human development approach provides a conceptual framework within which human rights principles can be incorporated into development planning and action because his theory of development as capability expansion defines the ultimate purpose of development as the expansion of human freedom). The 'human rights based approach' has gained momentum as an idea and is being adopted by several international NGOs and donor agencies in their development work. Yet many development practitioners and economists remain sceptical of this approach and its implementation has been partial. To assess the spread of this approach in government policy, the paper analysed Poverty Reduction Strategy Papers for 55 countries and finds only a few substantially engages with human rights as a development objective or integrate human rights principles into development strategies. The paper reviews the theoretical critiques and concludes that the obstacles to further implementation do not lie with inherent contradictions between human rights principles and development but with gaps in practical approaches. In particular, it identifies interpretation of the principle of indivisibility as a major obstacle; the absolutist interpretation leads to positions that amount to little more than sloganeering that undermines the credibility of the approach. More work is needed to analyse norms of human rights that relate to the duty bearer to promote human rights in development in economic, social and governance policies.
\end{abstract}

Journal of Economic Literature Classification: A14, F43, I31, J00, L39

Keywords: uman rights based approach to development; poverty; economic and social rights; capability approach; Amartya Sen; PRSP

Draft of paper to be included in a festschrift volume in honour of Amartya Sen's 75th birthday edited by Kaushik Basu and Ravi Kanbur, Oxford University Press, 2008 forthcoming. Research assistance from MA Hoekstra, M. Ashwill, L.Chiappa and C. Messineo is gratefully acknowledged.

The Economic Rights Working Paper Series of the University of Connecticut Human Rights Institute is an effort to gather the most recent work on Economic Rights. This paper is work in progress. The authors remain copyright holders of this paper.

This working paper is indexed on RePEc, http://repec.org/ 


\section{Introduction}

One of the important contributions of Amartya Sen has been to highlight the significance of human rights in development $(1981,1984,2005)$. Human rights is one of the key concepts, along with capabilities and functionings, entitlements, and fundamental freedom that Sen has used in defining the ultimate ends of development as expansion of capabilities and human freedom. The contribution of these ideas to economics and to the theory and practice of development is well known and documented, and has given rise to a vibrant body of new research and policy debates.

However, less well known among development economists is the significance of these same ideas to the field of human rights, particularly to the new and growing work on the role of human rights in poverty reduction and development. This is a new area of work for both theorists and practitioners. Sen's capability and human development approach provided a useful conceptual framework within which human rights principles could be incorporated because his approach defined the ultimate purpose of development as the expansion of human freedom (Alston 2005, Donnelly 2003, OHCHR 2004). In this way, human development (and the capability approach) and human rights then share a common motivation (UNDP 2000). The purpose of this paper is to draw on Sen's work to address current issues surrounding the concept and implementation of the 'human rights approach to development' (HRBA), and to encourage further research and policy debates in this area.

HRBA has spread wide among the key stakeholders in the development field (Maher and Marks, 2007). It is being adopted by increasing numbers of development actors including local and international NGOs, civil socie.ty groups, bilateral and multilateral donors, and think tanks. Increasing numbers of human rights scholars are interested in poverty reduction and development questions. Yet the implementation of HRBA remains uneven and still at the margins of both the fields of development and human rights. As most writers on the issue observe, the 'integration' of development and human rights has 
proven partial and difficult (Sano 2000; Gasper 2007; Uvin 2004; Alston and Robinson 2005). Uvin's analysis of development cooperation programmes (2004) shows that the adoption of HRBA by development cooperation agencies has been largely rhetorical and only a few have introduced new approaches to programme priorities and implementation. Other evaluations of the HRBA point to uneven experiences (ODI, 2006; Darrow 2007).

The truth is that many development practitioners remain highly sceptical of the idea of human rights as a central issue of development ends and means (Ingram and Freestone 2006). They continually ask 'what is the value added' (Alston and Robinson 2004; Kanbur 2007) to which the reply from the human rights community is that there is a need for 'value change' in development economics (Eide, 2006). Both communities face difficulty in integrating rights and development, characterized by Alston in his recent article (2005) as 'ships passing in the night' even though they are heading in the same direction.

These difficulties may be due to lack of communication as Alston suggests, or disagreement about the importance of human rights. This paper reviews the critiques to explore whether this is instead due to some limitations in the HRBA concept and practice to identify ways in which contradictions can be resolved and gaps filled.

\section{Human rights based development - the concept and policy agenda}

Starting in the late 1990's, human rights scholars and activists began to focus on global poverty. Concerned that the evolving global order was not adequately protecting and fulfilling human rights, they began to argue human rights are central to both the ends and means of the development process. This new attention grew out of the end of the Cold War, which then opened the way for the human rights community in the West to give more attention to economic and social rights. The rapid rise of civil society throughout the world and their global networks during this time was also a major factor. This activism took place within the UN system and the UN human rights machinery as Mary Robinson, the then UN High Commissioner for Human Rights, played a leading role, 
often singling out global poverty as the "biggest human rights challenge" of the day (2005; UNDP 2003). Her successor, Louise Arbour, continues to take this position, characterizing 'inequalities within and between countries' as a 'gravest human rights challenge' (2007. p. III).

A development discourse emerged, launched by a 1995 publication by the Human Rights Council of Australia, The Right Way to Development: Human Rights Approach to Development Assistance’ (HRCA 1995). While previously, human rights and development communities worked on joint agendas such as the passage of the Convention to Eliminate All Forms of Discrimination against Women, and the Convention on the Rights of the Child, or had tried to use development cooperation to put pressure on governments to stop human rights abuses, this was an initiative attempting to combine the two fields of endeavour that had previously developed in parallel and interacted little. The 'human rights based approach to development' (HRBA) sees development and human rights as pursuing the same objectives - defined as the realization of human rights and the respect of human rights principles in the process of development. In doing so, HRBA aimed to reorient development theory and practice. HRBA often refers to programme approaches adopted by development cooperation agencies that has introduced new priorities and activities. But these approaches are embedded in a broader 'discourse'. Here I use the term HRBA broadly, synonymously with 'human rights in development', to refer to the discourse.

\section{Social origins and motivations of HRBA}

By their very nature, human rights are ethical norms that are a product of 'social ethics and public reasoning' according to Sen (2006), or the history of 'social learning' according to Donnelly (2001). Human rights norms develop because people claim that certain conditions of human life are entitlements and demand that they become recognized as human rights. These norms also develop because people confront various threats to their survival as human beings (Shue, 1996). The recent emergence of HRBA must be understood as a demand driven by a concern with global poverty as an affront to human freedom and dignity, but also as a matter of injustice. Unlike economic analysis 
of poverty which looks to poor economic performance, inadequate resources or inadequate policies as the cause of poverty of countries, human rights is concerned with unequal distribution of power and wealth within and between countries.

HRBA holds duty bearers to account, demanding action to reverse these trends. It is thus a demand for alternative social arrangements including institutions of governance and economic-social policy regimes. More specifically, it is a challenge to globalization led by market liberalisation and global trade regimes, and to national policies of liberalisation and reforms of social protection. Additionally, HRBA is an endorsement and support to democratisation processes that enhance voices of people and accountability of government. According to Darrow and Tomas, 'ushered in during the 1990s in response to development failures of the structural adjustment era, human rights based approaches development have proliferated in recent years' (Darrow and Tomas, 2005). Similarly, Nelson and Dorsay explain 'The growing prominence of human rights in development discussions raises the first fundamental challenge to a market-dominated view of development that has prevailed since the 1980s' (Nelson and Dorsay, 2003).

\section{Key elements and its distinctiveness}

According to the OHCHR (2006), HRBA is "a conceptual framework for the process of human development that is normatively based on international human rights standards and operationally directed at promoting and protecting human rights. It seeks to analyse inequalities which lie at the heart of development problems and redress discriminatory practices and unjust distributions of power that impede development progress."

The key elements of this concept can be summarized into four points:

1) Overriding concern is human freedom and dignity;

2) Realization of human rights - all rights including economic, social, cultural, civil and political - by all individuals is a central objective of development;

3) Human rights principles should be part of the process of development. These include: a) equality and non-discrimination; 
b) participation of individuals especially in activities and decisions that affect their lives, and the empowerment of people;

c) accountability of the duty bearer to promote, protect and fulfil human rights;

d) indivisibility and interdependence of all human rights; ${ }^{1}$

e) obligations of progressive realisation, non-retrogression and immediate realisation of core minimum standards.

4) International human rights norms and standards should be applied in the development process and governments are accountable for their obligations arising from their commitment to international laws to which they are signatory.

All four of the above key elements are consistent with the priorities of the human development and capability approach to development. Human rights and human development (or capabilities) share a common motivation and commitment to human dignity and freedom (UNDP 2000). The relationship between the two are explored by both Sen $(1984,2004,2005)$ and Nussbaum (1997). They are different concepts, overlap considerably. In fact, Nussbaum notes: "Capabilities have a close relationship to human rights...In effect they cover the terrain covered by both the so-called first generation rights (political and civil rights) and the so-called second generation rights (economic and social rights)" (2003). They are both concerned with ensuring all individuals enjoy central capabilities or basic human rights that are of 'crucial importance in any human life' (Nussbaum 1997). But the two are not competing concepts but are complementary because they carry different functions. The fields of study of human rights and human development (and capabilities) have developed complementary sets of analytical tools and action approaches that can be deployed to meet the common goal of securing human dignity and freedom. Later sections of this paper will return to the different functionality of capabilities and human rights.

HRBA's policy agenda thus looks would be consistent with, and the human development agenda. It places high priority to achieving equity, meeting basic needs for survival and security but also participation, and promoting human agency. However, the HRBA

\footnotetext{
${ }^{1}$ Meaning that all human rights are individually important and should not be traded off one for another.
} 
brings distinct new features and emphasizes others more explicitly to the overall framework of human development.

First it is much more explicit about accountability; because human rights are explicitly entitlements, they impose claims on social institutions. So it draws attention to the need for institutional reforms to secure human rights, and the accountability of 'duty bearers'. Provisions such as education becomes a matter of accountability rather than one of charity. Second, it brings in the legitimacy of universal values and the clarity of internationally legislated norms, standards and obligations. Human rights are institutionally embedded in national and international legal instruments. HRBA bring legislation and litigation together as development policy tools. The third is the emphasis on equality, with attention to discrimination and to unequal power structures as a source of inequality and poverty. The fourth is the emphasis on participation and the process of development, of people being agents of change and making improvements in their own lives. This is a related notion of 'indivisibility and interdependence' by which it is meant that all human rights are individually valuable, and cannot be ordered in a hierarchy, and that the enjoyment of some rights are necessary for the realization of others. For example, the right to information is constrained if a person does not enjoy the right to education (Darrow and Tomas 2005).

HRBA's methods are quite distinct from conventional development practice. They include the conventional tools of human rights practice and new tools of development cooperation. The conventional tools mobilize the power of law and the power of ideas and include: litigation to secure remedies to individuals for violations; legislation of stronger law; social mobilization to demand accountability and put pressure on governments and other powerful actors such as corporations; naming and shaming to expose violations of human rights, and hold violators (duty bearers) to account. The new tools aim to empower people to demand their rights such as through human rights education, and to strengthen the institutions that protect human rights such as the ombudsman's office, reform of the justice system, strengthening the media. 


\section{HRBA as development practice: Mapping the spread and resistance}

Since the mid 1990s when HRBA began to spread, it has become a strong development discourse in international development. However, its spread has been uneven among actors and by implementation approach.

In the development community, many civil society groups and NGOs (including some leading national and international NGOs such as Oxfam, Care International, Save the Children and ActionAid) have started working with HRBA, some adopting it explicitly as a framework for the poverty work and emphasizing social justice rights as their core mission. For example, Oxfam International states: "Our mission is a just world without poverty and our goal is to enable people to exercise their rights and manage their own lives" (Oxfam International 2007). Similarly, ActionAid states "We work with local partners to fight poverty and injustice worldwide, reaching over 13 million of the poorest and most vulnerable people over the last year alone, helping them fight for and gain their rights to food, shelter, work, education, healthcare and a voice in the decisions that affect their lives."

Among bilateral development agencies, the adoption has varied from some with strong commitment to HRBA in their policy and programme priorities such as UK Department for International Development and Swedish International Development Agency, and the Norwegian Agency for Development who have prepared elaborate policies and guidelines, to others which have engaged little. But all have endorsed the principle of the importance of human rights under the OECD DAC policy of 1994 while the latest consensus policy document on HRBA adopted in January 2007 - 'Action-Oriented Policy Paper on Human Rights and Development' - recognizes human rights norms as "an accepted normative framework reflecting global moral and political values". It notes 'there is growing consensus on the value of human rights principles - such as participation, non-discrimination and accountability - for good and sustainable development practice. The application of these principles builds on and strengthens good 
and sustainable development practice, with equal attention to process and outcomes' (OECD DAC 2007).

Among the UN agencies, UNICEF has been a pioneer in this approach, building on their commitment to children's human rights in their involvement with the formulation and passage of the Convention on the Rights of the Child (CRC). UNICEF and other agencies such as UNDP have been developing policy positions and programme approaches since the 1990s. In the context of the coordinated programming strategy at the country level, the UN system as a whole has officially incorporated HRBA as one of the 'five inter-related principles that must be applied at the country level' along with gender equality, environmental sustainability, results-based management, and capacity development. (UNDG 2003), and developed a 'common understanding' of how this is to be implemented.

Implementation approaches can range from: (i) adoption of the language and 'rhetoric' as important ends; (ii) agenda reflecting HRBA priorities; ${ }^{2}$ and (iii) use of HR-specific tools and methods. According to recent reviews of development agency experience, (Uvin 2004; OECD/DAC 2005; Piron 2005) the adoption of the language of rights is widespread, but many have also shifted programme priorities, particularly in the governance areas to strengthen civil and political rights bsuch as access to justice. HRBA has been particularly relevant in raising issues of state-citizen linkages by use of the duty bearer-right holder and accountability perspectives, the structural roots of poverty and focus on exclusion as an obstacle (DAC/OECD 2005). The use of human rights instruments has been relevant in areas of women's rights drawing on CEDAW, children's rights drawing on CRC, and indigenous people. The DAC study concludes that there is a real danger of agencies claiming to use HRBA when all they are doing is 'rhetorical repackaging' of the same programmes with the same methods and agendas. This is one way of looking at the position that the World Bank took over many years:

\footnotetext{
${ }^{2}$ This in itself can be differenciated between human rights-based approaches, human rights mainstreaming, human rights projects, implicit human rights work, and human rights dialogue.
} 
stating that their programmes were in fact promoting human rights without using those terms. $^{3}$

Within the human rights community, there has been increasing engagement with poverty and development in the civil society organizations of all categories. While issues of poverty and social and economic rights have for long been a concern for human rights organizations in the south, northern NGOs not only neglected them but were actively hostile (Roth 2001; Neier 2003). But this has been changing gradually; Amnesty International, for example, began to look at economic and social rights in 2001, and their decision to focus on poverty for the 2008 global campaign marks a watershed in this new engagement. As for the UN machinery, a wealth of important new initiatives have been taken since the 1990s. For example, Special Rapporteurs have been appointed on Extreme Poverty, on the Right to Development, Health, Food and other relevant issues, and the UN High Commission has been an active advocate while the secretariat work of the OHCHR in this area has begun important work in areas such as developing guidelines in the HRBA approach to poverty reduction.

These are important innovations and show significant spread of HRBA as development practice. But they remain limited and have remained at the margins of both human rights and development practice. HRBA has had little impact on some of the major actors, most notably the Bretton Woods institutions and the other multilateral economic agencies including UNCTAD, WTO and even UNDESA. Its reach has not extended to most national governments of the Global South, with some notable exceptions such as Brazil and South Africa. It has had little impact on the main programme work of governments supported by the international community, namely the Millennium Development Goals (MDGs) initiative and the Poverty Reduction Strategy Papers (PRSPs).

\section{Human rights agendas in MDGs}

\footnotetext{
${ }^{3}$ This was a consistent line taken in World Bank statements in addressing the human rights community in the 1990s. See for example, statements by World Bank representative Alfredo Sfeir Younus to UN meetings in Geneva in the 1990s. See also Wolfensohn in Alston and Robinson 2005.
} 
In his 2005 article on MDGs and human rights, Alston surveys in detail the integration of human rights in MDG processes (Alston 2005). Despite the fact that MDGs and HRBA have substantially overlapping objectives, employ similar approaches and involve some of the same actors, human rights agendas are barely integrated into key MDG initiatives such as in the MDG monitoring reports prepared at the country level.

As for the human rights community, the importance of MDGs has been amply recognized in a number of resolutions and reports; according to Alston, 'at the superficial level, the Commission has been assiduous, even admirable, in relation to the Millennium Declaration and the MDG's. Yet these were only passing references, even in resolutions that dealt with issues such as housing, right to food, and education. MDGs have not been included in the substantive work of the experts, nor of the work of the Special rapporteurs on a variety of themes and countries. Only a few cases were exceptions to this trend, including the 2004 report of the special rapporteur on health, and the working group on the right to development. Alston concludes that 'MDGs have not been taken on board in any sustained way’. (p. 819)

Human rights agendas in Poverty Reduction Strategy Papers (PRSP)s

Similar trends are apparent in the PRSPs surveyed for this paper. Alston's conclusions on the MDGs can be applied to the review of PRSPs of 55 countries (23 in Asia, 24 in Africa, 7 in Latin America and 1 in the Middle East). Poverty Reduction Strategy Papers (PRSPs) are the national policy frameworks for poverty reduction that countries prepare on the basis of which international support is mobilized, so they reflect the policy priorities of national governments which are supported by official donors.

Like the human rights commission resolutions, PRSPs made ample mention of the term 'human rights', and if not human rights, rights. Only a handful of PRSPs (Eritrea, Ethiopia, Grenada, Guinea Bissau, Haiti, Pakistan, and Tajikistan) made no mention of either term. However, in many of them, the reference was scant - in 28, it was 
mentioned less than 10 times - often not appearing until well into the document totalling some 200-300 pages. In most, the reference was general and made in passing terms, often in context of a general statement of a development vision, and no sections devoted to human rights or human rights institutions. In some, it refers only to civil and political rights. In most, there is scant reference to the nature of human rights violations and challenges such as the discrimination against minorities or ethnic majorities, or the analysis of poverty from the human rights perspective such as the roots of poverty in institutionalized discrimination and lack of power.

The term participation is used multiple times in almost all the PRSPs reviewed. It is mostly used to refer to participation in the PRSP formulation process which is a mandated methodological feature. Participation has been the focus of pressure by HRBA advocates and supporters in shaping PRSPs, and it is one of the aspects of PRSPs that have been scrutinized and criticized (Stewart 2005; Piron and Evans 2004; UNDP). While guidelines recommend that national strategies be based on broad consultation with people, many of the consultation processes have been criticized as being pro-forma meetings with NGOs, often with international NGOs. Participation is also referred to as local contribution such as in Eritrea. Or there may be a mention of participation with no reference to any substantive analysis or program. From the human rights perspective, real participation is about people having a say in decisions that are made and being able to hold authorities to account. Processes such as this need to be institutionalized and go beyond ad hoc meetings, and would also require carefully designing a system of voice with accountability, not just voice without response. There is little reference to the broad concept of government accountability for human rights. But transparency and sometimes accountability appear in many PRSPs in relation to good governance.

Equality and equity are consistently mentioned, but most often in relation to gender equality only. And several countries (Pakistan, Guinea Bissau, Central African Republic, Chad) miss out on this issue altogether, not mentioning even once the terms equality, inequality, or equity. What's more, the terms 'discrimination' and 'nondiscrimination' - distinctive principles of HRBA - are rarely used. 
HRBA agendas are missing in countries where they are clearly serious issues. For example, only some - not all - countries that have experienced civil war with serious civil rights violations refer to human rights. For example, Angola, Afghanistan and Cambodia emphasize human rights as a priority in relation to national reconciliation, stability and social order, democracy and peace. No mention is made of such issues in Haiti, Eritrea, Ethiopia_ countries still facing civil strife where impunity for past abuses and ethnic discriminations are still live issues.

Only a handful of countries have prepared PRSPs that go beyond rhetorical use of the term 'human rights' and associated principles of equality, participation and accountability. But these exceptional cases are especially interesting documents that incorporate some elements of the human rights perspective on poverty and development. The Rwanda PRSP is framed in the HRBA perspective, starting in the introduction with the fulfillment of human rights as the over-riding objective of development. It states "The Government of Rwanda strongly believes in the right of all its people to live a life free from poverty, hardship, oppression and security. Rwanda's government is committed to securing for all its citizens a full range of social, economic and political rights and to working with its people to reduce poverty and exclusion." HRBA elements and principles are a central factor in several strategy areas, such as good governance which is to ensure accountability and transparency, gender equality and innovative participatory methods for identifying the poor and monitoring poverty reduction process. Inequality is defined in income and non-income spaces and receives focussed attention in both analysis of poverty and as a consequence of policy options. Uganda's PRSP also focuses more explicitly on aspects of the HRBA agenda, particularly inequality and accountability. However, it does not give much attention to the inequalities related to the ethnic strife in the North.

Another country that has prepared the PRSP from the HRBA perspective is East Timor. This PRSP looks at the relationship between human rights and poverty and goes beyond the conventional PRSP issues and emphasizes the need for a culture of respect for human 
rights, especially for women, children and vulnerable groups, and the important role of the media. These are not the only countries that have incorporated human rights in the PRSPs. Human rights are one of the three main pillars of the government in Afghanistan. Burkina Faso develops a specific approach to promoting human rights as part of the democratic governance pillar of the program. A few other countries such as Ghana, Angola (draft), and Liberia (interim) include significant attention to human rights in different ways.

It is not surprising that some of the countries most committed to adopting HRBA to frame the PRSPs are those emerging from war, including Rwanda, Liberia, East Timor and Cambodia. Yet it is also surprising when it is not a element of post conflict countries strategies, such as in Haiti and Sierra Leone.

\section{HRBA as practice - critiques, gaps, contradictions}

Why has HRBA remained at the margins of development policy? Are the reasons political? HRBA is being championed by the international community and sometimes by national civil society, rarely by developing country governments. As already emphasized, human rights are tools of social pressure applied by people to challenge authority structures. It is therefore not surprising that 'official' government programmes such as the PRSP's and MDG's do not incorporate human rights agendas. Moreover, in the international context, use of human rights has been to bring reputational damage to developing country governments or to sanction them. So developing country governments prefer to keep the topic out of discussion in their relations with the international community. HRBA is thus intrinsically contradictory to international cooperation since it generates conflict and challenges to power (Darrow and Tomas 2005).

Is the resistance due to a mindset, a legacy of the Cold War thinking combined with libertarian ideology, that rejects the principle of social and economic rights, insisting that only civil and political rights are 'real'? This is a view that is still widely held, along with the common (and misguided) understanding of human rights as divided into two 
categories of civil and political rights as one set and economic and social rights as another, with distinct differences such as that civil and political rights are "negative rights' and social and economic rights are 'positive' rights, and challenging the validity of the latter because of lack of a legal basis for identifying violations and responsibilities. ${ }^{4}$ Thus Ingram and Freestone, in the introduction to the special issue on human rights of the World Bank publication 'Outreach' (2006) write 'many development practitioners - including World Bank staff - typically think of human rights abuses in terms of violations of civil or political rights, actions not necessarily associated with economic development and often perceived as neutral in terms of their impact on economic growth. Many would even argue that the provision of civil and political liberties would generally follow from sustained economic growth or is even a by-product of growing prosperity, a view that has tended to dominate the World Bank's own institutional thinking about human rights.'

This position is rooted in the writings of Bentham, who held that 'natural rights' is 'nonsense upon stilts', that continues in the writings of many influential philosophers and legal scholars. Such positions are reflected in the popular press, for example, in a recent editorial leader in the Economist magazine commenting on Amnesty's campaign against global poverty, entitled 'Stand up for your rights: The old stuffy ones, that is, newer ones are distractions' (Economist, March 24, 2007).

Or has there been inadequate communication between the human rights and development communities? These two fields have evolved in parallel until now, and have well established literature of conceptual, empirical, and policy work that have rarely been shared. They have operated through two separate disciplines of law on the one hand and economics on the other. Is the lack of effective integration of agendas due to failures to understand? The literature on critiques of HRBA is limited and it is difficult to pin down.

\footnotetext{
${ }^{4}$ For example, Ingram and Freestone, in the introduction to the World Bank publication 'Outreach's issue on human rights (2006) states 'many development practitioners - including World Bank staff - typically think of human rights abuses in terms of violations of civil or political rights, actions not necessarily associated with economic development and often perceived as neutral in terms of their impact on economic growth. Many would even argue that the provision of civil and political liberties would generally follow from sustained economic growth or is even a by-product of growing prosperity, a view that has tended to dominate the World Bank's own institutional thinking about human rights'.
} 
Uvin (2004), Darrow and Tomas (2005), Robinson (2005) and Gasper (2007) provide useful reviews. Most often, development practitioners do not challenge human rights as offering normative guidance and framework for development. But they frequently comment puzzlement over the 'value added' of HRBA to accelerating the process of development, or to the analysis of policy choices. Mary Robinson (2005) recounts the major criticisms of HRBA expressed by development practitioners as being: too political and adversarial; unrealistic, expecting reform to be effective over-night, ignoring the underlying weaknesses of state capacity and social structures that are the reasons for major human rights concerns; abstract, appealing to high principle but not concerned with policy choices where trade-offs are required; ignore time and sequence, and do not take into account the realities of development process which takes a long time, and which sometimes need to regress in order to progress, and too legalistic, relying on law that does not work in the context of weak institutional frameworks.

These critiques relate to both concept and methodology. Do these critiques arise from tensions or fundamental contradictions between human rights and development? Are there limitations to the HRBA? Or have the methods not been well developed since it is a new approach still in the making?

\section{Methodology: Legislation and litigation}

The methods of human rights promotion has historically used the power of law and ideas that are inherent in human rights. Passing stronger legislation and litigation have been effective instruments for defending and enforcing human rights in many countries. The fact that human rights are backed by law and so can be rigorously defined and enforced is in fact the distinct strengths of human rights, and gives it unique instrumental value. Since human rights are more than morally defined value but subject to binding legal obligations that can be subject to legal claims by citizens and accountability processes in international treaty bodies, they have a unique instrumental power. 
One critique of HRBA is that the legal instruments are ineffective, and thus irrelevant, in developing country contexts. The use of these instruments assumes that the state is both capable and willing to protect the rights of all citizens, including the poor and marginalized (Robinson 2005; Gasper 2007). The reality is that the court system everywhere (not just in developing countries) is often tipped in favour of the rich and powerful who have greater access to it and the means to influence and use it effectively.

Courts are admittedly particularly ineffective in developing country contexts where a functioning, non-biased legal system does not exist in defending the rights and interests of poor people in a strategy to defend their rights. Yet increasing use of legal instruments and the course to defend the rights and interests of poor people is one of the new and effective ways in which human rights - and poverty reduction - is being advanced. For example, in a series of celebrated cases in India, the courts have established housing as a necessary means to the constitutionally guaranteed right to life, giving people protection from forced evictions if no alternative housing was arranged. In Dominican Republic more than 70,000 slum dwellers were allowed to remain in their homes in defiance of a presidential decree after the UN Committee on Economic, Social and Cultural Rights condemned planned eviction (UNDP 2000). It is true that constitutional guarantees for human rights are often a dead letter but bringing these to a test has been a means of human rights defenses. In Argentina, constitutional guarantees for citizens rights to seek state protection was put to test when people living with HIV/AIDS were denied access to healthcare and medication.

Thus the problem of court systems that tip in favour of the rich can be overcome when poor people make alliances with public defenders, or civil society human rights defenders. And in the longer term, when reforms strengthen, the judicial system can have important consequences for security rights of poor people which could have multiple implications for poverty reduction and development. Poor people can defend their rights to land, for example, and save themselves from falling into destitution. Poor women can defend themselves from being sold into trafficking. Such actions can have implications not only for the well being of the person affected, but could contribute to economic growth 
through productivity gains. Thus one of the major thrusts of HRBA as development practice has been to provide resources and other means to support programmes to strengthen access to justice. The instrumental value of the legal tools of human rights on development has been demonstrated for example by Agarwal who has shown that women's position is related to land rights, and more recently to urban property rights to a house that can be legally enforced (Agarwal 1994; Agarwal and Panda 2007).

Nonetheless, the critique of the legal instrumentality also reveals the need for much better understanding of the instrumentality of human rights as law. Under what conditions and in what ways does it empower poor people and their multiplier effects on society in expanding opportunities and economic growth? What are the conditions in which legal enforcement of rights could be counterproductive? A common critique of human rights is its pursuit of one specific right without regard to its consequences. Glendon (1991), in her critique of 'rights talk' in America, argues that the excess of demands of individual rights without regard to the social context and community has come to impoverish American political debates. In the same way, excesses of the individual pursuit of rights at the expense of attention to the concerns of community can become counterproductive to development goals. Disputes over resettlement, for example, between individual rights to livelihood and the 'development objectives' of expanding power supply and irrigation reflect such tensions between individual rights and development. These points will be taken up later in the paper under conceptual issues.

\section{Methodology: Naming and shaming}

Investigating abuses, bringing public exposure to shame the offender to effect behaviour change has historically been the principal tool of human rights activism. However, naming and shaming however can be counterproductive in the context of development cooperation. Naming and shaming assumes that realization of rights is a matter of will and can be achieved overnight. It does not take account of the fact that realizing rights requires institutions, capacity and resources (UNDP 2000). For example, the right to education cannot be achieved overnight, but requires building schools and training 
teachers. This applies not only to economic and social rights but also civil and political rights. Access to justice requires building courts, as well as training lawyers and judges.

Naming and shaming by international governments and NGOs also ignores the role of geo-politics in international dialogue on human rights. The use of human rights finger pointing is selective, most often targeted against developing countries and their governments by the powerful industrialized countries led by the US and Western Europe, often motivated by political or economic interests. Well meaning international human rights activism in civil society can become a tool of geo-political manoeuvres. Naming and shaming is more likely to be effective when civil society targets their own governments, or corporations (UNDP 2000).

Naming and shaming is directly contrary to the methodology of development cooperation and is quintessentially about going beyond finding problems to finding solutions. While human rights successes have been built on a mobilization of social movements, changes in law, and legal remedy for individual cases, development builds on policy change, building institutions and building infrastructure that open up economic, social and political opportunities. Its professional, analytical work is based on empirical analysis and assessment of policy options.

In a well-known article, Kenneth Roth, the President of Human Rights Watch argues that the strength of international human rights organisations, like his own, is in the methodology of naming and shaming to effect behaviour change (Roth 2004). This methodology is only appropriate in cases of arbitrary discrimination and disregard for human rights, where there is a clear violation, violated, and violator. He also argues that much of the human rights issues related to poverty, and to social and economic rights do not fall into this category, because they are 'social justice' issues, often related to economic policy issues where the 'right' policy is a matter of debate. Thus it is hard to argue that a person's right to education or food has been compromised or violated as a result of a particular economic policy. He concludes therefore that the engagement of international human rights organizations on these issues should remain limited. 
He rightly argues that advocacy needs to go beyond exposing the denial of rights, and that unless effective remedy can be advocated, public outrage at widespread poverty is mere 'sloganeering'. He further argues that while the public might be outraged by widespread poverty - such as child dies of lack of health care - they would have 'no idea whom to blame', or that 'the blame is dispersed among a wide variety of actors. In such cases of diffuse responsibility, the stigma attached to any person, government, or institution is lessened, and with it the power that international human rights organizations can have to effect change. Similarly, stigma weakens even in the case of a single violator if the remedy to a violation-what the government should do to correct it-is unclear'.

Much as Roth's arguments are convincing, they also pinpoint a major weakness in current human rights methodology. The problem is not that it is impossible to identify the violator and remedy, but that HRBA has not yet developed the tools to do so. For example, in the case of a child who dies due to lack of health care, it is true that human rights specialists - mostly lawyers, political scientists, philosophers and social activists do not know much about alternatives approaches to expanding healthcare. But they can partner with the specialists to identify key policy variables and alternatives, and hold to account those who could do more, and pressure for policy reform. In fact, strong international intellectual property protection has kept prices of life-saving medicines such as AIDS retrovirals inaccessibly high. Pressure from some governments of the Global South, and development NGOs and think tanks using a combination of solid technical analysis of policy alternatives and targetted name and shame tactics quite successfully forced governments and pharmaceutical companies to shift policy on the TRIPS agreement on intellectual property and drug pricing.

Some human rights organizations are beginning to engage with policy analysis and alternatives but this practice remains limited and not the general practice. So HRBA naming and shaming too often exposes the denial of a human right - 'child dies of treatable illness' - but stops short of identifying the real violation and the violator which is the inadequate action of the duty bearer to respect, protect and fulfil its obligations for the child's right to healthcare and to life. 
International NGOs such as Human Rights Watch and Amnesty International are powerful forces in global governance. If they are to play a role in addressing what the UN High Commissioner calls the 'gravest challenge' in human rights, they need to go invest in new partnerships with the development community's policy analysts to advocate reforms in the economic, social and governance reforms that constitute violations.

\section{Conceptual issues - Indivisibility if rights}

The principles of indivisibility and inter-relatedness are a cornerstone of HRBA, but are also the most problematic. They are a source of the major critique that HRBA as being unrealistic and abstract and therefore offering little practical value in development planning for the practitioner. The principle of indivisibility holds that all human rights are necessary for a life of freedom and dignity, each one being individually valuable and none being more important than another. ${ }^{5}$ It rejects the notion of hierarchy among rights, and any basis for considering economic and social rights as less important than civil and political rights. Furthermore, it is argued that human rights are 'interdependent', meaning that the rights are not mutually inconsistent and enjoyment of one right facilitates - or makes possible - the enjoyment of another right. For example, without the enjoyment of right to life, all other rights cannot be accessible. Or without the enjoyment of right to education, right to work would be curtailed. From the point of view of human development practice, it means that the promotion of human rights should not be subject to hierarchy - but should be pursued simultaneously, in a 'holistic' manner.

For the development practitioner, particularly economists, this immediately raises the question of priorities in allocating resources and effort since not all problems can be tackled at once. It has long been recognized among human rights theorists that the realization of economic and social human rights was subject to resource constraints. It has become increasingly acknowledged that civil and political rights are also subject to

\footnotetext{
${ }^{5}$ UHDR makes clear that all rights are equally important. The concept of 'indivisibility' is affirmed in the 1986 Declaration of the Right to Development; and the 1993 Vienna Declaration and Programme of Action
} 
resource constraints. For example, adequate institutions and infrastructure are required to vote as much as to access healthcare. In both cases, it requires financial, human and other material resources for investment in these facilities as well as to run them. The central task of development planning and policy-making is allocating resources among competing priorities. The HRBA principles of indivisibility thus would seem to close off all possibility for such allocation, particularly when combined with an absolutist adherence to human rights norms for each and every right of each and every individual as non-negotiable. HRBA becomes abstract and unrealistic.

Human rights theorists and institutions have responded to this issue with the principle of 'progressive realization' - that state parties' obligation for realization of economic and social rights must take account of historical reality, institutional and resource constraints, to be realized progressively. But this is hardly a solution since more recently the Committee on Economic, Social and Cultural Rights clarified that states have the obligation for immediate, rather than progressive, realization of essential minimum standards, to remove discrimination, as well as for non-retrogression. All of these three obligations ignore the same institutional and resource constraints that apply.

Another related proposal has been to develop a concept of certain development activities as entitlements. (Sano 2000; Andreassen 1997). But this comes up against the same problem as minimum standards.

The difference between essential minimum standards and human rights norms is difficult to interpret. The reality is that in most of the 60 or so low human development countries of the world, large proportions of people are in poverty, measured either by the monetary measure of $\$ 1$ a day or by capability deprivation such as the Human Poverty Index. The index ranges from 30-65\% for countries (UNDP 2005) with available data showing that a third to two thirds of the population do not enjoy basic subsistence rights (Shue 1980). In many of these countries recent progress has been very slow, in part because economic growth has been stagnant, (World Bank 2007, Fukuda-Parr 2007, UNDP 2003) and demonstrates that immediate realization of minimum standards is not a realistic goal. 
The fact that at the global level the world is far from achieving the Millennium Development Goals shows that meeting essential minimum standards is far from being realized - and to realize it immediately is indeed unrealistic.

Even removal of discrimination requires resources and institutional reforms; for example removing discrimination against girls education in many contexts requires training female teachers, installing adequate toilets for girls, and public debates about the value of girls education and the equal rights of women to shift mindsets of community leaders and parents. The principle of non-retrogression denies any possibility of leaving individuals worse off.

In fact, as a review by Gasper (2007) and Uvin (2004) show, the human rights community has been 'averse to admitting conflicts of rights', and has not done enough to address this issue. Leading scholars and practitioners such as Alston and Robinson urge the community to engage more in addressing the issue (2005). If this were to be pursued, it would be useful to make two kinds of distinctions. The first would be to distinguish between prioritizing resource use rather than prioritizing rights, and the second would be to distinguish between conflicting rights and their consequences.

Prioritizing rights or resource use: The principle of indivisibility and interdependence contradicts prioritizing among rights or individuals but it does not contradict the need to prioritize resource use. As Darrow and Tomas emphasize, the indivisibility of rights 'does not mean that all rights must be elevated to the same level of priority in programmatic terms. Resource and institutional constraints will often require the prioritization and realization of different rights for the purposes of policy choice' (Darrow and Tomas 2005 p.503).

The attention of HRBA therefore should focus on empirical analysis of resource allocations in national budgets, in donor budgets, in NGO budgets, and so on. This analysis will need to use the tools and information base of development economics to analyse and critique government policy positions. The work being done on critical 
analysis of budgets from the point of view of child rights, or of women's rights - gender budgeting - is an example of how HRBA can address resource issues. But such approaches can be expanded and applied to other areas that are relevant to the promotion of human rights. For the economist seeking the 'value added' of HRBA, such exercises will show that HRBA brings new questions that policy makers will need to answer.

Yet another path would be to further work on the state-citizen relationship and the state capacity to meet its human rights obligations. Human rights are interdependent not only from the rights holder perspective but also the duty-bearer perspective. Just as an individual cannot enjoy a life of dignity and freedom with a piecemeal realization of rights, a state is unlikely to commit to its human rights obligations piece-meal. The nature of the state and the state-citizen relationship is therefore fundamental to the realization of rights. But another condition of a state able to protect, respect and fulfill the rights of citizens is its institutional and financial capacity. HRBA needs to focus more on expanding the capacity of the state to meet its obligations, and expanding the resource base of the state. Here again, economic analysis will be needed such as on choices in taxation policy.

However, another view sees human rights as inherently not about a tool for resource allocation but as a tool for political action to challenge 'elite capture' in an environment of power asymmetries (Darrow and Tomas, 2005). Ultimately, there are no 'technocratic' answers to priorities that societies might set. Economics help analyse the efficiency of resource use, but the ultimate decision depends on how the benefits are evaluated. Human rights bring ethical values into evaluating the benefits. The instrumentality of human rights is to resolve competing claims through the courts (Darrow and Tomas, 2005). Another way would be through democratic, participatory consultation processes (Sen 2004; Osmani 2005).

Conflicting rights or consequences of policy: The principle of indivisibility and interdependence would be consistent with recognizing that action to fulfill one right can conflict or take back enjoyment of another right or the rights of other individuals. For 
example, as Basu (1999) and others have argued, a policy to prohibit child labour such as trade sanctions on export products manufactured with child labour would drive out children from say carpet weaving for exports, but the consequence would be that the child and family suffer hunger and other privations, or that the child is sent to even more exploitative work such as prostitution. Critics say that HRBA does not recognize the need for sequencing. In fact, such policy positions are never a simple matter of trade-offs but policy choices may be found that would achieve most to protect the child's human rights.

The principle of indivisibility and inter-dependence would see all enjoyment of human rights to have a positive impact for the duty holder. But from the duty bearer perspective, policy action to protect and fulfill one right may have negative consequences on other rights. Precisely because of the complex inter-relatedness of human rights in human lives, the repercussions are strong and important. Investigating consequences would be critical then to the further strengthening of HRBA. In such cases, it would also be important to clarify and distinguish between what can be ethically acceptable to 'trade-away' and what cannot (Basu 2007).

\section{Human rights and development - the way forward}

This review has shown that there are no inherent contradictions between human rights principles and development. Human rights principles are not contradictory to the demands of prioritization.

The absolutist interpretation of human rights principles of indivisibility is simplistic and does not recognize the complexity of the concept nor of the contexts in which the principle is being applied. This leads to blind adherence to principles that amounts to little more than sloganeering, and when combined with the passionate zeal of the human rights defender, detracts from rather than builds the credibility of HRBA. Indivisibility does reject placing rights in a hierarchy of importance. But that is not inconsistent with

prioritization in the use of resources. The concrete challenge would be to develop the 
tools of analysis and advocacy that challenge resource use that are inconsistent with human rights priorities.

There are major limitations in the toolkit of HRBA that stops short of identifying violations that lie in policies - economic, social and governance - that reflect shortcomings of human rights obligations. The human rights field, dominated by law, philosophy and political science, has not engaged with real options for policy. The development field, on the other hand, dominated by economists and technical specialists focusses on the analysis of policy options. Vibrant studies and debates are on-going. But these studies and debates are not connected to the normative priorities that human rights frameworks indicate. It is often thought that economists have the 'right answers' to policy choice and that human rights would have little to add. In fact,there are no 'right policy choices'; economic and technical analysis can analyse policy alternatives pointing out which ones are most economically efficient, or technically effective. But the policy choice depends on ethical choices over such trade offs as between disincentives to pharmaceutical companies to invest in innovation and expanding access to life saving drugs today. It is the role of human rights to guide such policy choices.

But conventional analysis of policy options is not being done with human rights norms in mind. Yet all development policies - economic, social, governance - have huge implications on the fulfilment of human rights. Macroeconomic policies such as taxation have enormous impacts on human rights outcomes and choices governments make in this area determine whether government is doing enough to respect, protect and fulfil human rights (Balakrishnan 2003). Recent work such as analysis of budgets and impact on child rights, and an analysis of economic policies and state obligations under CEDAW (Elson 2006) are important examples of policy analysis for human rights. These are important beginnings in developing new tools.

Naming and shaming, social mobilization are unique tools of human rights. Human rights have unique power of ideas and to empower. But unless matched with a more careful analysis of the policy options and identifying the real violation, human rights 
advocacy on poverty will be a mere rhetorical use of the term, turning it into a manifesto right.

HRBA and the project to integrate human rights and development into a single undertaking, with common motivations and objectives, complementary and coherent methods and strategies is still in the making. While critics from within the human rights field such as Roth (2004) propose a highly selective approach to invoking human rights concepts and activism on poverty issues, others such as Alston and Robinson (2004; Alston 2005) call for greater engagement. Still others such as Sano (2001) have pointed out that the two fields cannot be fully integrated. The shortcomings of the HRBA identified in this paper would point to a need for greater integration. As Nussbaum explains (1997) in comparing capabilities with human rights, we need the concept of capabilities and functionings to evaluate how societies are faring, to be able to make comparisons between the past and the present, between countries, and so on. The role of human rights on the other hand has a different focus, to help develop ethical norms that guide designs on institutional arrangements. ${ }^{6}$

As concepts, the merger of human development and human rights is not a question but a fact. The idea of entitlement and human rights is an integral part of the concept of capabilities (Sen 1984). While the two concepts are not the same, they are more integrally inter-connected than sharing broad visions. As noted in the 2000 Human Development Report, Human rights and human development are close enough in motivation and concern to be congruous and compatible, and they are different enough in strategy and design to supplement each other fruitfully. A more integrated approach can thus bring significant rewards, and facilitate in practical ways the shared attempts to advance the dignity, well-being and freedom of individuals in general' (UNDP 2000 p.19).

\footnotetext{
${ }^{6}$ see Nussbaum 1997 for an exploration of the relationship between human rights and capabilities.
} 


\section{$\underline{\text { References cited }}$}

Andreassen, Bard-Anders 1997. "Assessing Human Rights Performance in Developing Countries: The Case for a Minimal Threshold Approach to Economic and Social Rights in Developing Countries" A Yearbook on Human Rights in Countries Receiving Nordic Aid.

Agarwal, Bina, 1994. A Field of Her Own: Gender and Land Rights in South Asia, Cambridge, Cambridge University Press

Agarwal, Bina and Pradeep Panda, 2007. "Toward Freedom from Domestic Violence: The Neglected Obvious" Journal of Human Development Vol 8 Nr. 3 November 2007

Alston, Philip. 2005 'Ships Passing in the Night: The Current State of the Human Rights and Development Debate seen through the Lens of the Millennium Development Goals' Human Rights Quarterly 27. pp 755-829

Alston, Philip and Mary Robinson, 2004. Human Rights and Development: Towards Mutual Reinforcement. Oxford University Press. New York

Amnesty International, 2005. Human Rights for Human Dignity: A primer on economic, social and cultural rights. http://web.amnesty.org/library/Index/ENGPOL340092005?open\&of=ENG-AGO

Basu, Kaushik, 2003. Global Labour Standards and Local Freedoms, WIDER Annual Lecture 7. http://www.wider.unu.edu/publications/annual-lectures/annual-lecture2003.pdf

Basu, Kaushik, 1999. 'Child Labor: Causes, Consequences and Cure, with Remarks on International Labour Standards”, Journal of economic Literature 37, pp.108-119

Basu, Kaushik 2007. in Hertel and Minkler, eds. Economic Rights: Conceptual, Measurement and Policy Issues. Cambridge University Press. New York

Balakrishnan, Radhika. 2005. Why MES with Human Rights: Integrating Macroeconomic Strategies with Human Rights

Darrow, Mac. 2007. Personal correspondence

Darrow, Mac and Amparo Tomas, 2005. 'Power, Capture and Conflict: A Call for Human Rights Accountability in Development Cooperation', Human Rights Quarterly May 2005. 27.2 p. 471-538 .

Donnelly, Jack. 2006. Universal Human Rights: In Theory and Practice. (Third edition) Westview Press. 
Economist, "Stand up for your rights: The old stuffy ones, that is, newer ones are distractions" March 242007

Eide, Asbjorn, 2006. "Human Rights Based Development in an Age of Economic Globalization" in Bard Andreassen and Stephen Marks, eds. Development as a Human Right. Nobel Symposium book. Harvard School of Public Health. Boston

Gasper, Des. 2007. "Human Rights, Human Needs, Human Devleopment, Human Secureity: Relationships between Four International 'Human' Discourses”. Forum for Development Studies No. 1-2007. pp 9-42

Glendon, Mary Anne, 1991. Rights Talk

Ingram, Joe and David Freestone, 2006. 'Human Rights and Development" Development Outreach October 206. world Bank Institute, Washington D.C.

Ravi Kanbur, 2007. 'Attacking Poverty: What is the Value Added of a Human Rights Approach?’ www.people.cornell.edu/pages/sk145

Marks, Stephen and Ajay Mahal. 2007. Goals and Instruments of Poverty Reduction: Economic and Human Rights Perspectives on children's Rights and Development Strategies.

Nelson, Paul and Ellen Dorsey, 2003. 'At the Nexus of Human Rights and Development: New Methods and Strategies of Global NGOs', World Development vol. 31. no. 12 pp 2013-2026

Neier, Aryeh. 2003. Taking Liberties: Four decades $n$ the struggle for rights. New York. Public Affairs.

Nussbaum, Martha. 1997. 'Capabilities and Human Rights' Fordham Law Review 66. reprinted in Patrick Hayden, ed. The Philosophy of Human Rights. Paragon House, St. Paul, Minnessota

ODI, 2006. "Human Rights and Poverty Reduction: Realities, Controversies and Strategies" http://www.odi.org.uk/rights/Publications/Rights\%20Meeting\%20Series\%20Publication \%202006/intro_screen.pdf

OECD, Development Assistance Committee (DAC), 2007. 'Action-Oriented paper on Human Rights and Development'. DCD/DAC(2007)15 OECD, Paris.

OHCHR, 2004. Human Rights and Poverty Reduction: A Conceptual Framework. http://ohchr.org/english/issues/povertyguidelines.htm 
OHCHR, 2007. 'Mary Robinson, United Nations High Commissioner for Human Rights (1997-2002), http://www.unhchr.ch/html/hchr/unhc.htm, accessed 09.10.07

OHCHR, 2006. Frequently Asked Questions on a Human Rights-Based Approach to Development Cooperation. http://ohchr.org

Osmani, Siddiqur, 2004. "Human Rights' Journal of Human Development

OXFAM America 2007. Mission statement.

http://www.oxfamamerica.org/whatwedo/our_approach/ (accessed Sept 29, 2007)

Piron, Laure-Helen and Alison Evans, 2004. "Politics and PRSP: Synthesis Paper", London, ODI

Piron, Laure-Helene, 2005 'Integrating Human Rights into Development: a synthesis of donor approaches and experiences' ODI, London. Prepapred for the OECD/DAC Netowrk on governance (GOVNET). http://www.odi.org

Roth, Kennth. 2004. 'Defending Economic, Social and Cultural Rights: Practical Issues Faced by an International Human Rights Organization'. Human Rights quarterly 26. pp63-73.

Robinson, Mary. 2005. 'What Rights Can Add to Good Development Practice' in Alston and Robinson, 2005 Human Rights and Development:Towards Mutual Reinforcement. New York, Oxford University Press

Sen, A. K. 1981. Poverty and Famines: An Essay on Entitlement and Deprivation. Oxford: Clarendon.

Sen, Amartya 1984. "Resources, Values and Development" Harvard University Press, Cambridge

Sen, Amartya. 1989. 'Development as Capability Expansion' Journal of Development Planning 1989. no. 19 pp 41-58 reprinted in Fukuda-Parr, S. and Shiva Kumar, eds. 2003. Readings in Human Development, Oxford University Press, New Delhi

Sen, Amartya. 1999. Development as Freedom. Alfred Knopf Publishers, New York.

Sen, Amartya, 2004. 'Elements of a theory of human rights' Philosophy and Public Affairs 34(4): 315-56

Sen, Amartya, 2005. "Human Rights and Capabilities" Journal of Human Development. Vol. 6 No. 2, pp. 151-166 
Sen, Amartya, 2006. 'Human Rights and Development' in Andreassen and Marks, eds. Development as a Human Right: Legal, Political, and Economic Dimensions, Harvard School of Public Health, Distributed by Harvard University Press, Cambridge Mass.

Sano, Hans-Otto, 2000. 'Development and Human Rights: The Necessary, but Partial Integration of Human Rights and Development'. Human Rights Quarterly 22 (2000) pp 734-752. The Johns Hopkins University Press

Shue, Henry 1996. Basic Rights: Subsistence, Affluence and U.S. Foreign Policy $2^{\text {nd }}$ ed. Princeton University Press, Chichester

Stewart, Frances and Michael Wang, 2005. 'Poverty Reduction Papers within the Human Rights Perspective', chapter 17 in Alston and Robinson, Human Rights and Development:Towards Mutual Reinforcement, New York, Oxford University Press

UNDG 2003. 'Common Understanding on Human Rights Based Approach to Development Programming of UN Agencies' (adopted at the Second Interagency Workshop on Implementing a Human Rights-based Approach in the Context of UN Reform in 2003, Geneva, 2003. subsequently endorsed by UN Development Group.

UNDP 2000. Human Development Report: Human Rights, New York, Oxford University Press

UNDP xxxx Evaluation of PRSPs

Uvin, Peter. 2004. Human Rights and Development, Kumarian Press, Bloomfield, Ct.

PRSPs published on World Bank website as of 20 September, 2007 www.worldbank.org - including latest documents of Afghanistan, Albania, Armenia, Azerbaijan, Bangladesh, Bhutan, Bosnia \& Herzegovina, Cambodia, Georgia, Indonesia, Kyrgyz Republic, Laos, Macedonia, Moldova, Mongolia, Nepal, Pakistan, Serbia \&Montenegro, SriLanka, Tajikistan, East Timor, Uzbekistan, Vietnamm, Angola, Burkina Faso, Cameroon, Central African Republic, Chad, Congo, Cote d'Ivoire, Djibouri, Eritrea, Ethiopia, Ghana, Guinea, Guinea Bissau, Lesotho, Madagascar, Malawi, Mali, Mauritania, Nigeria, Rwanda, Senegal, Sudan, Uganda, Bolivia, Dominican Republic, Grenada, Guyana, Haiti, Honduras, Nicaragua, Yemen. 